\title{
Fire effects on a Spartina densiflora salt marsh in the floodplain of the Paraná River, Argentina
}

\author{
Efectos del fuego en una marisma de Spartina densiflora en la planicie de inundación \\ del río Paraná, Argentina
}

NORA MADANES*, SYLVIA FISCHER \& RICARDO VICARI

\begin{abstract}
Departamento de Ecología, Genética y Evolución, Facultad de Ciencias Exactas y Naturales, Universidad de Buenos Aires, Pabellón II, Ciudad Universitaria, C1428EHA Buenos Aires, Argentina;

*e-mail for correspondence: noram@ege.fcen.uba.ar
\end{abstract}

\begin{abstract}
We studied the effects of fire on the structural attributes of a Spartina densiflora salt marsh. The study was carried out from November 1995, spring (N95S) to December 1996, late spring (D96LS). In November 1995, we installed 37 permanent plots. In January 1996, 32 of the plots were accidentally burned (B) and the remaining were not burned (NB). Vegetation on each plot was sampled seasonally, plant species were identified and cover-abundance was estimated. We analyzed and compared seasonal variations in plant species richness, diversity, composition and cover-abundance in burned and non-burned plots. In addition, we analyzed variations in biological types (forbs, graminoids) and types of life cycles (annuals, perennials) in B and NB plots before and after the fire.Principal Component Analysis (PCA) was performed on coverabundance data for each treatment and sampling date. We included coded dummy variables for each date and treatment as supplementary variables. Results indicated that $S$. densiflora was the dominant species and Limonium brasiliensis and Dipsacum fullonum were the accompanying species for all treatments and sampling dates. Thirty out of 47 species were present before the fire (N95S). All species in NB plots were also recorded in B plots, and 15 species were exclusively found in B plots. The increases in species richness and diversity observed in B plots after the fire were higher than those in NB plots at the same sampling dates. When comparing the B plots before and after the fire, perennials decreased in cover-abundance and increased in richness, while both attributes increased for annuals; the same pattern was followed by forbs, and graminoids decreased in cover abundance and showed almost similar values of richness. PCA results showed that NB plots were subject to smooth temporal changes in composition and cover abundance, and that B plots underwent greater changes. In D96LS, B and NB plots exhibited a different spatial distribution, which in turn differed from that observed in pre-fire plots in N95S.
\end{abstract}

Key words: Spartina densiflora, salt-marsh, fire, community.

\section{RESUMEN}

En este trabajo estudiamos el efecto del fuego sobre atributos estructurales de una marisma de Spartina densiflora. El estudio se realizó desde noviembre de 1995, primavera (N95P) hasta diciembre de 1996, primavera tardía (D96PT). En noviembre se instalaron 37 parcelas permanentes, en enero de 1996, 32 (Q) se quemaron accidentalmente mientras que cinco no (NQ). La vegetación de cada parcela fue muestreada estacionalmente. Las especies fueron identificadas y su cobertura-abundancia estimada. Analizamos y comparamos las variaciones estacionales en la riqueza específica, diversidad, composición y coberturaabundancia en parcelas Q y NQ. Los tipos biológicos (latifoliadas y graminiformes) y de ciclos de vida (anuales y perennes) fueron comparados antes (N95P) y después del fuego (D96PT) en las parcelas Q y NQ. El análisis de componentes principales (PCA) se realizó en base a la cobertura-abundancia de las especies por parcela para cada fecha y tratamiento. La especie dominante fue $S$. densiflora. Las acompañantes Limonium brasiliense y Dipsacum fullanum estuvieron presentes en todas las fechas de muestreo y tratamientos. En total se identificaron 47 especies, 30 de las cuales estuvieron presentes antes del fuego. Todas las especies presentes en las parcelas NQ lo estuvieron en las Q en las cuales 15 especies fueron exclusivas de este tratamiento. Los incrementos en riqueza de especies y diversidad fueron mayores en las parcelas Q que en las NQ para las mismas fechas. Cuando las perennes se compararon en las parcelas Q antes y después del fuego, se encontró que disminuyeron en cobertura-abundancia e incrementaron su riqueza; mientras que ambos valores s incrementaron en las anuales, el mismo patrón siguieron las latifoliadas mientras que las 
graminiformes disminuyeron sus valores de cobertura-abundancia pero la riqueza permaneció similar. Los resultados del PCA mostraron que las parcelas NQ estuvieron sujetas a cambios temporales, en composición y cobertura-abundancia de las especies, menores que las Q y que en D96PT las parcelas Q y NQ mostraron una distribución espacial diferente de la observada en N95P.

Palabras clave: Spartina densiflora, marismas, fuego, comunidad.

\section{INTRODUCTION}

A disturbance is regarded as any process involving the partial or total destruction of biomass from a community (Grime 1979). Disturbances are classified as either lethal or non-lethal on the basis of their severity, each one leading to different vegetation responses (Baldwin \& Mendelsson 1998). Lethal disturbances cause the removal of the dominant perennial and the subsequent colonization by other plant species via recruitment from propagules dispersed into the disturbed patch (Nyman \& Chabreck 1995). In contrast, nonlethal disturbances do not remove the dominant perennials, which will displace colonizing species with the consequent recovery of the community structure to pre-disturbance levels (Baldwin \& Mendelsson 1998). Fire is one of the main disturbing agents in vegetation communities, and leads to complex effects with interacting changes in light climate, soil surface temperature and nitrogen availability (Hulbert 1988), as well as in the structural attributes of the disturbed community (Grace et al. 2001).

Salt marshes are subject to natural and anthropic disturbances affecting community structure and dynamics. Coastal salt marshes are strongly influenced by wrack deposition, salt water intrusion, hurricanes and oil pollution. Riverine salt marshes are usually affected by hydrologic alterations, fire and cattle rising, and both types of wetlands are exposed to climate change. Communities of Spartina spp. are physiognomically homogeneous and characterized by salttolerant, accompanying vegetation composed of species and/or genuses common to most Spartina salt-marshes (Mitsch \& Gosselink 2000). Spartina salt marshes usually display a remarkable low diversity of species. For example, salt marshes of Spartina alterniflora Loiseleur, Spartina patens (Aiton) Muhl. and Spartina pectinata in central USA form extensive monospecific stands along the rivers (Nekola \& Lammers 1989, Orme 1990).
In Argentina, tall grasslands are very common both in the Pampean and Chaquenian regions of the neotropics (Cabrera \& Willink 1980). On inland marshes and depressed areas with holo hidrophic soils, Spartina densiflora and $S$. argentinensis are often the dominant species of tall grasslands (Feldman \& Lewis 2005). In tall grasslands of $S$. argentinensis, fire can be considered as a dynamic process that plays an important role in shaping community structure (Lewis et al. 1990, Feldman \& Lewis 2005). In these communities, spontaneous or man-made fires are frequent during summer droughts, or after very cold and dry winters due to high accumulation of aboveground biomass (Feldman \& Lewis 2005). The Spartina salt marsh in the Lower Delta of the Paraná River is dominated by $S$. densiflora, with Salicornia virginica, Limonium brasiliense and Atriplex hastata as accompanying species (Chichizola 1993). An accidental human-caused fire that occurred while conducting a survey in the $S$. densiflora community mentioned above, provided an opportunity to investigate the response of the community to that disturbance. To achieve this goal, we analyzed and compared seasonal variations in plant species richness, diversity, composition and cover-abundance in burned and non-burned plots during one-year period. In addition, we analyzed variations in biological types and types of life cycles in burned and non-burned plots before and after the fire.

\section{MATERIAL AND METHODS}

\section{Study site}

The Otamendi Natural Reserve $\left(34^{\circ} 10^{\prime} \mathrm{S}\right.$, $58^{\circ} 48^{\prime} \mathrm{W}$ ) covers an area of 2,380 ha (Fig. 1). At a regional level, the Reserve is part of an extensive alluvial plain of a flat-concave relief dominated by freshwater marshes, but it has been classified as a salt marsh by Mitsch \& 
Gosselink (2000). Saline environments are related to the geological history of the area, since marine sediments lying at a very shallow depth were deposited during the Querandinense period of marine ingression in the early Holocene (Iriondo \& Scotta 1978).

The Reserve is located in the Lower Delta of the Paraná River flood-plain, which forms the lower section of Del Plata Basin, one of the largest South American basins together with those of the rivers Amazon and Orinoco. The flooding regime is mainly determined by the combination of the hydrologic regime of the Río de la Plata river and rainfall (Kandus et al. 2004). The floods produced by the Paraná River only take place during extraordinary events usually related to "El Niño" (Málvarez \& Bó 2002). The climate is warm-humid, with an annual mean temperature of $16.3{ }^{\circ} \mathrm{C}\left(22.6{ }^{\circ} \mathrm{C}\right.$ January mean, $10.5{ }^{\circ} \mathrm{C}$ July mean), and accumulated annual rainfall ranging between 900 and $1000 \mathrm{~mm}$. Frosts are frequent during the fall-winter period (INTA 1998). The vegetation is a mosaic of herbaceous and woody communities, and includes elements from the Pampeana, Espinal and Paranaense Biogeographic Provinces (Chichizola 1993).

The $S$. densiflora salt marsh occupies a 440ha area of clayish and marshy soils, with salinities ranging from 10 to $35 \mathrm{ppt}$ (Chichizola 1993). It is characterized by the occurrence of winter floods originated by seasonal rains and insufficient drainage, owing to the closeness of the ground-water table to the surface. During the summer months, soils remain relatively dry (Bonfils 1962).

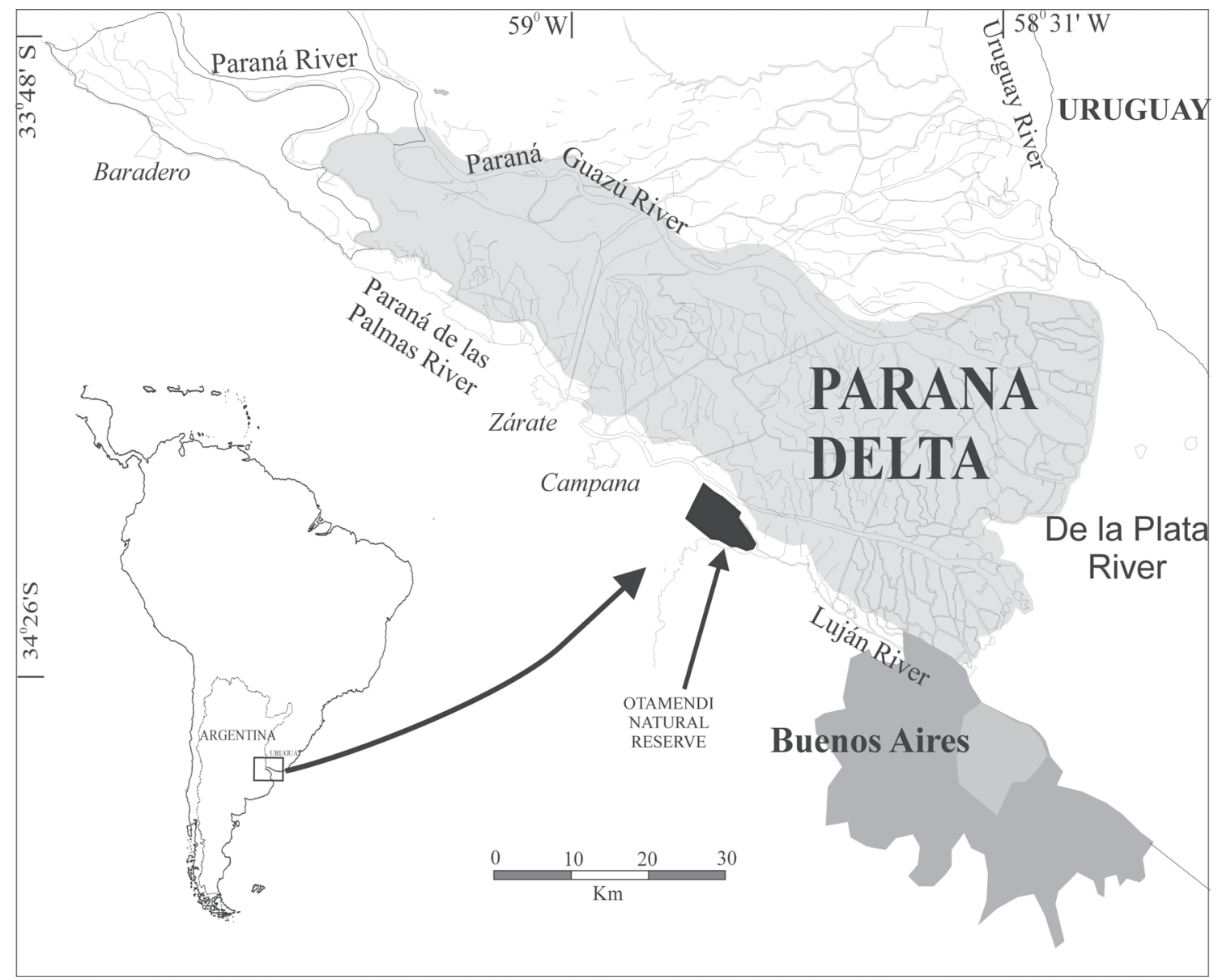

Fig. 1: Location of the Otamendi Natural Reserve.

Ubicación de la Reserva Natural Otamendi. 
The $S$. densiflora salt marsh is frequently affected by accidental fires (Juber \& Entrocasi 2000), particularly during the summer. On January 26, 1996, an accidental fire affected 50 $\%$ of the salt marsh surface. As a result, whitish-gray ashes were spread over the ground, and blackish ashes accumulated in the center of bunch-grasses (Vicari et al. 2002).

\section{Sampling procedure}

The study was carried out from November 1995 to December 1996. In November 1995, we installed 37 permanent 5 x 5 m plots. In January 1996, 32 of the plots were burned (B); the remaining were not burned and served as a control (NB). Vegetation on each plot was sampled seasonally for one year during the following sampling dates: (i) before fire: November 1995, spring (N95S); (ii) after fire: March 1996, late summer (M96LSu), July 1996, winter (J96W) and December 1996, late spring (D96LS). All plant species were identified in the field and in the laboratory following Cabrera \& Zardini (1993) for adult individuals and Petetin \& Molinari (1977) for seedlings. In addition, species were characterized according to their growth form (Raunkiaer 1937). Cover-abundance of each species was estimated using modified BraunBlanquet (1979) scale; the cover-abundance value was assigned using the following scale: $r$ $=0.01,+=0.5,1=3,2=7.5,3=17.5,4=29$, $5=41.5,6=62.5,7=87.5$. We also estimated the proportion of litter and bare soil for each plot.

\section{Data analysis}

Mean cover-abundance and standard deviation of each species were calculated for the burned $(\mathrm{n}=32)$ and non-burned $(\mathrm{n}=5)$ plots at each sampling date. The frequency of each species per sampling date and treatment was calculated by summing the number of plots where the species was recorded (Mueller-Dombois \& Ellemberg 1974). Species were classified and ordered according to their mean coverabundance, frequency and presence in each treatment and at each sampling date.

Vegetation species were grouped by biological type as forbs $(F)$ or graminoids $(G)$ (Barkman 1988), and by type of life cycle as annuals (A) or perennials (P) (Cabrera \& Zardini 1993). In each category, the percentage of cover-abundance was calculated by summing the cover-abundance of all the species, and richness by summing the species present. The values obtained for each category were then compared between burned and non-burned plots at the beginning and end of the study by using the nonparametric Wilcoxon's test for dependent samples (Zar 1996).

Mean diversity per treatment and sampling date was obtained using the Shannon-Weaver index $\left(\mathrm{H}^{\prime}\right)$; a similar procedure was applied to obtain mean species richness and mean evenness (Magurran 1991).

The ordination of species was performed by principal component analysis (PCA) on coverabundance data (square-root transformed) using a data matrix of 47 species $x 148$ plots that included all dates and considered both treatments together. Dummy variables with codes for each date and treatment were included as supplementary variables. We used program CANOCO, version 3.12 (ter Braak 1995). Species present in a single plot and/or showing an accumulated cover-abundance lower than $5 \%$ were not included in the analysis.

\section{RESULTS}

Species recorded are listed in Table 1. The total number of species in $\mathrm{B}$ and NB plots during the entire study period was 47,30 of which were already recorded in N95S. During the followup period after the fire, there were 12 species in the NB plots and 21 in the B plots. All species in NB plots were also recorded in B plots, and 15 species were exclusively found in B plots. Spartina densiflora was the dominant species and $L$. brasiliensis and D. fullonum were the accompanying species for all treatments and sampling dates. The accompanying species showed low frequencies and their coverabundance values were higher than $10 \%$ for at least one sampling date (Table 1). The species included in the group from $A$. tribuloides to $S$. rhombifolia were present in low frequency and cover-abundance in both treatments at all dates. Species included in the group from $D$. microcalyx to $R$. hilariana were present before the fire, and were observed at very low 
frequency and cover-abundance in B plots at different dates. Only some of the species included from $A$. hastata to $P$. monspeliensis were present before the fire, showing low frequencies and cover-abundance values in both B and NB plots. However, this group of species reached the highest values in D96LS. Finally, one group was registered only in the B plots, and most of its species were present in D96LS.

\section{TABLE 1}

Plant species, biological types (F: forbs; G: graminoids; S: shrubs; HC: herbaceous climbing plants), types of life cycles (A: annuals; P: perennials), mean percent cover-abundance $(\bar{x})$, standard deviation (SD) and frequency $(\mathrm{F})$ of each species before and after fire in burned $(\mathrm{n}=32)$ and nonburned $(\mathrm{n}=5)$ plots along the study period: N95S, November 1995, spring; M96LSu, March 1996, late summer; J96W, July 1996, winter and D96LS, December 1996, late spring

Lista de especies, categorías de las formas de forma de vida (AR: arbustivas; HL: herbáceas latifoliadas; HG: herbáceas graminiformes; EH: enredaderas herbáceas), tipos de ciclo de vida (A: anual; P: perennes); media porcentual de la cobertura abundancia $(\bar{x})$, desvío estándar (DE) y frecuencia de las especies en las parcelas, antes y después del fuego quemadas $(n=32)$ y no quemadas $(n=5)$ durante el período de estudio: N95S, noviembre 1995, primavera; M96Lsu: marzo1996, verano tardío; J96W, julio 1996, invierno y D96LS, diciembre 1996, primavera tardía. Se indican también la media porcentual de la cobertura $(\bar{x})$, desvío estándar (DE) y frecuencia (F) de la broza y el suelo desnudo

\begin{tabular}{|c|c|c|c|c|c|c|c|c|c|c|c|c|c|c|}
\hline \multirow[t]{4}{*}{ Especie } & \multirow[b]{4}{*}{ BT } & \multirow[b]{4}{*}{ LC } & \multicolumn{12}{|c|}{ (A) Burned } \\
\hline & & & \multicolumn{6}{|c|}{ Before fire } & \multicolumn{6}{|c|}{ After fire } \\
\hline & & & \multicolumn{3}{|c|}{ N95S } & \multicolumn{3}{|c|}{ M96LSu } & \multicolumn{3}{|c|}{ J96W } & \multicolumn{3}{|c|}{ D96LS } \\
\hline & & & $\bar{x}$ & SD & F & $\bar{x}$ & SD & $\mathrm{F}$ & $\bar{x}$ & SD & $\mathrm{F}$ & $\bar{x}$ & SD & $\mathrm{F}$ \\
\hline Spartina densiflora Brong. & $\mathrm{G}$ & $\mathrm{P}$ & 72.9 & 20.1 & 32 & 8.0 & 10.1 & 31 & 20.4 & 19.0 & 30 & 15.9 & 13.4 & 32 \\
\hline Limonium brasiliense (Boiss) O. Kuntze & $\mathrm{S}$ & $\mathrm{P}$ & 8.1 & 8.2 & 24 & 3.7 & 7.2 & 31 & 11.6 & 16.8 & 32 & 9.1 & 8.2 & 27 \\
\hline Dipsacus fullonum $\mathrm{L}$. & $\mathrm{F}$ & $\mathrm{P}$ & 0.1 & 0.4 & 2 & 0.0 & 0.0 & 3 & 0.0 & 0.1 & 4 & 0.3 & 1.5 & 3 \\
\hline Acicarpha tribuloides Juss. & $\mathrm{F}$ & A & 0.2 & 1.1 & 4 & & & & 0.6 & 1.0 & 25 & 9.1 & 10.4 & 26 \\
\hline Rumex obovatus Danser. & $\mathrm{F}$ & $\mathrm{P}$ & 0.3 & 1.2 & 4 & 0.0 & 0.0 & 6 & 0.4 & 0.5 & 18 & 5.0 & 5.6 & 25 \\
\hline Apium sellowianum H.Wolff & $\mathrm{F}$ & $\mathrm{A}$ & 0.8 & 2.2 & 7 & 0.0 & 0.0 & 1 & 0.0 & 0.1 & 6 & & & \\
\hline Salicornia virginica $\mathrm{L}$. & S & $\mathrm{P}$ & 0.7 & 1.5 & 14 & 0.6 & 1.8 & 24 & 1.7 & 5.8 & 24 & & & \\
\hline Cynodon dactylon (L.) Pers. & $\mathrm{G}$ & $\mathrm{P}$ & 0.0 & 0.1 & 1 & 0.0 & 0.0 & 10 & 0.0 & 0.1 & 5 & & & \\
\hline Sida rhombifolia $\mathrm{L}$. & $\mathrm{S}$ & $\mathrm{P}$ & 0.4 & 1.2 & 6 & 3.6 & 9.4 & 13 & 1.6 & 7.0 & 7 & & & \\
\hline Dichondra microcalyx (Hallier) nov.st. & $\mathrm{F}$ & $\mathrm{P}$ & 0.4 & 2.0 & 1 & 0.0 & 0.0 & 1 & & & & 3.5 & 5.3 & 19 \\
\hline Portulaca sp. L. & $\mathrm{F}$ & $\mathrm{P}$ & 0.0 & 0.1 & 1 & & & & 0.0 & 0.0 & 3 & & & \\
\hline Carduus acanthoides $\mathrm{L}$. & $\mathrm{F}$ & $\mathrm{P}$ & & & & & & & & & & 6.3 & 7.2 & 26 \\
\hline Plantago major $\mathrm{L}$. & $\mathrm{F}$ & $P$ & 0.3 & 1.1 & 2 & & & & & & & & & \\
\hline Centaurium pulchellum (Sw.) Druce & $\mathrm{F}$ & A & & & & & & & & & & 1.9 & 3.4 & 11 \\
\hline Muehlembeckia sagittifolia (Ort.) Meissn & $\mathrm{HC}$ & $\mathrm{P}$ & & & & & & & & & & 0.4 & 1.3 & 9 \\
\hline Heliotropum curassacicum $\mathrm{L}$. & S & $\mathrm{P}$ & & & & & & & & & & 0.2 & 1.0 & 5 \\
\hline Rorippa hilariana (Walp.) Cabr. & $\mathrm{F}$ & $P$ & 0.0 & 0.1 & 1 & 0.0 & 0.0 & 10 & 0.0 & 0.1 & 5 & & & \\
\hline Atriplex hastata $\mathrm{L}$. & $\mathrm{F}$ & A & & & & 0.0 & 0.0 & 13 & & & & 3.2 & 4.2 & 23 \\
\hline Oxalis conorrhiza (Feullé) Jacq. & $\mathrm{F}$ & $\mathrm{P}$ & & & & & & & & & & 0.6 & 1.9 & 7 \\
\hline Cynara cardunculus L. & $\mathrm{F}$ & $\mathrm{P}$ & 0.9 & 3.1 & 13 & 0.0 & 0.0 & 2 & & & & 0.9 & 1.9 & 20 \\
\hline Coronopus didymus (L.) Smith. & $\mathrm{F}$ & A & & & & 0.2 & 0.7 & 3 & 2.9 & 11.3 & 8 & 2.6 & 5.1 & 14 \\
\hline Apium leptophillum (Pers.) F. Muell. & $\mathrm{F}$ & A & 0.1 & 0.4 & 2 & 0.0 & 0.0 & 3 & 0.0 & 0.1 & 4 & 0.3 & 1.5 & 3 \\
\hline Cirsium vulgare (Savi) Airy-Shaw & $\mathrm{F}$ & $\mathrm{P}$ & 0.4 & 1.2 & 6 & 3.6 & 9.4 & 13 & 1.6 & 7.0 & 7 & & & \\
\hline Lepidium bonariense $\mathrm{L}$. & $\mathrm{F}$ & A & & & & & & & & & & 0.2 & 0.9 & 4 \\
\hline Salicornia ambigua Mich. & S & $\mathrm{P}$ & & & & & & & 0.5 & 1.5 & 19 & & & \\
\hline Sida sp. L. & S & $\mathrm{P}$ & & & & & & & 0.1 & 0.2 & 22 & & & \\
\hline Melilotus officinalis (L.) Lam. & F & A & & & & & & & & & & 0.4 & 1.0 & 12 \\
\hline Petunia parviflora Juss. & $\mathrm{F}$ & A & 0.8 & 2.1 & 12 & & & & & & & & & \\
\hline Polypogon monspeliensis (L.) Desf. & G & A & 0.0 & 0.0 & 1 & 0.0 & 0.0 & 2 & 0.1 & 0.5 & 4 & 0.2 & 0.6 & 5 \\
\hline Eleocharis sp. R. Br. & $\mathrm{G}$ & $\mathrm{P}$ & 0.0 & 0.1 & 1 & & & & & & & 1.9 & 2.9 & 19 \\
\hline Spergularia levis Camb. & $\mathrm{F}$ & $\mathrm{P}$ & & & & 0.1 & 0.5 & 21 & & & & & & \\
\hline
\end{tabular}


TABLE 1 (continuation)

Especie

(A) Burned

\begin{tabular}{|c|c|c|c|c|c|c|c|c|c|c|c|c|c|}
\hline \multirow[b]{3}{*}{ BT } & \multirow[b]{3}{*}{ LC } & \multicolumn{6}{|c|}{ Before fire } & \multicolumn{6}{|c|}{ After fire } \\
\hline & & \multicolumn{3}{|c|}{$\mathrm{N} 95 \mathrm{~S}$} & \multicolumn{3}{|c|}{ M96LSu } & \multicolumn{3}{|c|}{ J96W } & \multicolumn{3}{|c|}{ D96LS } \\
\hline & & $\bar{x}$ & SD & F & $\bar{x}$ & SD & F & $\bar{x}$ & SD & F & $\bar{x}$ & $\mathrm{SD}$ & F \\
\hline $\mathrm{F}$ & $\mathrm{P}$ & 0.8 & 2.3 & 5 & & & & & & & & & \\
\hline $\mathrm{F}$ & $\mathrm{P}$ & 0.4 & 2.2 & 5 & & & & & & & 0.0 & 0.0 & 3 \\
\hline F & $\mathrm{P}$ & 8.1 & 8.2 & 24 & 3.7 & 7.2 & 31 & 11.6 & 16.8 & 32 & 9.1 & 8.2 & 27 \\
\hline F & $\mathrm{P}$ & & & & & & & & & & 0.2 & 1.0 & 2 \\
\hline $\mathrm{F}$ & A & 0.8 & 2.2 & 7 & 0.0 & 0.0 & 1 & 0.0 & 0.1 & 6 & & & \\
\hline $\mathrm{F}$ & A & & & & & & & & & & 1.3 & 2.1 & 18 \\
\hline G & A & & & & 0.3 & 1.1 & 4 & 0.1 & 0.5 & 1 & 0.0 & 0.0 & 1 \\
\hline F & A & 0.7 & 1.5 & 14 & 0.6 & 1.8 & 24 & 1.7 & 5.8 & 24 & & & \\
\hline F & $\mathrm{P}$ & & & & & & & 0.2 & 0.5 & 17 & & & \\
\hline $\mathrm{F}$ & $\mathrm{P}$ & 0.2 & 1.1 & 4 & & & & 0.6 & 1.0 & 25 & 9.1 & 10.4 & 26 \\
\hline $\mathrm{F}$ & $\mathrm{P}$ & & & & 0.0 & 0.0 & 4 & 1.8 & 4.3 & 25 & 0.2 & 1.0 & 2 \\
\hline $\mathrm{F}$ & A & & & & & & & & & & 5.5 & 8.0 & 24 \\
\hline G & $\mathrm{P}$ & & & & & & & & & & 0.0 & 0.0 & 1 \\
\hline G & $\mathrm{P}$ & 0.1 & 0.6 & 3 & & & & & & & 0.0 & 0.1 & 5 \\
\hline G & $P$ & & & & 0.0 & 0.0 & 2 & & & & 7.4 & 6.0 & 29 \\
\hline $\mathrm{F}$ & A & & & & & & & & & & 0.3 & 1.3 & 3 \\
\hline & & 8.9 & 15.8 & 19 & 71.9 & 18.8 & 32 & 42.7 & 22.8 & 30 & 17.8 & 11.2 & 31 \\
\hline & & 3.4 & 4.9 & 26 & 0.3 & 1.5 & 3 & 0.6 & 1.9 & 4 & 0.0 & 0.0 & 0 \\
\hline
\end{tabular}

Phyla canescens (H.B.K.) Greene.

Plantago tomentosa Lam.

Ambrosia tenuifolia Sprengel

Gnaphalium sp. L.

Cerastium glomeratum Thuill.

Euphorbia serpens Kunth.

Spergularia sp. J.et C. Presl

Chenopodium album $\mathrm{L}$.

Rumex crispus $\mathrm{L}$.

Aster squamatus (Spreng.) Hieron

Cressa truxillensis H.B.K.

Brassica campestris $\mathrm{L}$.

Distichlis spicata (L.) Greene.

Picrosia longiflora Don

Carex sp. L.

Lythrum hyssopifolia $\mathrm{L}$.

Bare soil

Litter

Spartina densiflora Brong.

Limonium brasiliense (Boiss) 0. Kuntze

Dipsacus fullonum L.

Acicarpha tribuloides Juss.

Rumex obovatus Danser.

Apium sellowianum H.Wolff

Salicornia virginica $\mathrm{L}$.

Cynodon dactylon (L.) Pers.

Sida rhombifolia $\mathrm{L}$.

Dichondra microcalyx (Hallier) nov.st.

Portulaca sp. L.

Carduus acanthoides L.

Plantago major L.

Centaurium pulchellum (Sw.) Druce

Muehlembeckia sagittifolia (Ort.) Meissn

Heliotropum curassacicum L.

Rorippa hilariana (Walp.) Cabr.

Atriplex hastata L.

Oxalis conorrhiza (Feullé) Jacq.

Cynara cardunculus L.

Coronopus didymus (L.) Smith.

Apium leptophillum (Pers.) F. Muell.

Cirsium vulgare (Savi) Airy-Shaw

Lepidium bonariense $\mathrm{L}$.

Salicornia ambigua Mich.

Sida sp. L.

Melilotus officinalis (L.) Lam.

Petunia parviflora Juss.

Polypogon monspeliensis (L.) Desf.

Bare soil

Litter

$\begin{array}{llllllllllll}0.3 & 16.1 & 5 & 16.0 & 19.7 & 4 & 17.6 & 14.5 & 5 & 13.0 & 8.5 & 4\end{array}$

\begin{tabular}{|c|c|c|c|c|c|c|c|c|c|c|c|c|}
\hline $\mathrm{G}$ & $\mathrm{P}$ & 67.6 & 10.2 & 5 & 75.9 & 24.4 & 5 & 71.1 & 22.5 & 5 & 38.4 & 28.2 \\
\hline S & $\mathrm{P}$ & 7.3 & 4.2 & 5 & 1.5 & 3.0 & 5 & 1.5 & 1.9 & 5 & 5.4 & 10.2 \\
\hline $\mathrm{F}$ & $\mathrm{P}$ & 2.9 & 6.2 & 2 & 0.0 & 0.0 & 2 & 2.1 & 3.1 & 3 & 16.0 & 19.3 \\
\hline $\mathrm{F}$ & A & 0.2 & 0.3 & 2 & & & & 2.6 & 5.4 & 3 & 3.4 & 4.7 \\
\hline $\mathrm{F}$ & $\mathrm{P}$ & 0.1 & 0.3 & 1 & & & & 0.0 & 0.0 & 1 & 4.0 & 2.4 \\
\hline $\mathrm{F}$ & A & 3.8 & 5.6 & 2 & 0.0 & 0.0 & 3 & 0.1 & 0.2 & 1 & & \\
\hline S & $\mathrm{P}$ & 2.1 & 3.8 & 4 & & & & 0.0 & 0.0 & 1 & & \\
\hline $\mathrm{G}$ & $\mathrm{P}$ & 0.1 & 0.2 & 1 & & & & & & & & \\
\hline S & $\mathrm{P}$ & 0.7 & 1.2 & 2 & 0.0 & 0.1 & 1 & & & & & \\
\hline $\mathrm{F}$ & $\mathrm{P}$ & 0.1 & 0.3 & 1 & & & & & & & & \\
\hline $\mathrm{F}$ & $\mathrm{P}$ & 0.1 & 0.2 & 1 & & & & & & & & \\
\hline $\mathrm{F}$ & $\mathrm{P}$ & 0.1 & 0.3 & 1 & & & & & & & & \\
\hline $\mathrm{F}$ & $\mathrm{P}$ & 0.2 & 0.3 & 2 & & & & & & & & \\
\hline $\mathrm{F}$ & A & 0.1 & 0.3 & 1 & & & & & & & & \\
\hline $\mathrm{HC}$ & $\mathrm{P}$ & 0.1 & 0.3 & 1 & & & & & & & & \\
\hline S & $\mathrm{P}$ & 0.1 & 0.2 & 1 & & & & & & & & \\
\hline $\mathrm{F}$ & $\mathrm{P}$ & 0.1 & 0.3 & 1 & & & & & & & & \\
\hline $\mathrm{F}$ & A & & & & 0.1 & 0.1 & 2 & & & & & \\
\hline $\mathrm{F}$ & $\mathrm{P}$ & & & & & & & & & & 1 & \\
\hline $\mathrm{F}$ & $\mathrm{P}$ & & & & & & & & & & 1 & \\
\hline $\mathrm{F}$ & A & & & & & & & & & 1 & 0.0 & 0.1 \\
\hline $\mathrm{F}$ & A & & & & & & & & & & 4.4 & 3.1 \\
\hline $\mathrm{F}$ & $\mathrm{P}$ & & & & & & & & & & 2.0 & 2.7 \\
\hline $\mathrm{F}$ & A & & & & & & & & & & 0.0 & 0.0 \\
\hline S & $\mathrm{P}$ & & & & & & & & & & 0.5 & 1.1 \\
\hline$S$ & $\mathrm{P}$ & & & & & & & & & & 4.2 & 4.5 \\
\hline $\mathrm{F}$ & A & & & & & & & & & & 2.0 & 2.7 \\
\hline $\mathrm{F}$ & A & & & & & & & & & & 1.0 & 2.1 \\
\hline G & A & & & & & & & & & & 1.0 & 1.3 \\
\hline & & 10.3 & 16.1 & 5 & 16.0 & 19.7 & 4 & 17.6 & 14.5 & 5 & 13.0 & 8.5 \\
\hline & & 4.3 & 5.5 & 5 & 1.1 & 2.2 & 4 & 4.2 & 7.5 & 4 & 5.8 & 7.7 \\
\hline
\end{tabular}


When comparing the cover-abundance of $S$. densiflora before (N95S) and after the fire (D96LS), differences were not significant in NB plots but significant in B plots (Fig. 2A, Table 2). In the NB plots, the cover-abundance and richness of the $\mathrm{A}, \mathrm{P}$, and $\mathrm{G}$, and the richness of the $\mathrm{F}$ did not show significant differences between N95S and D96LS; however, a significant increase was observed in the cover-abundance of the F (Fig. 2B-2E).

Fig. $2 \mathrm{~B}$ and $2 \mathrm{C}$ show that the coverabundance and richness of the $\mathrm{P}$ were higher than those of the A for both treatments before and after the fire. In the B plots, the different plant categories showed the following trends after the fire: $\mathrm{P}$ showed a significant decrease in cover-abundance and a significant increase in richness, while A increased significantly in cover-abundance and richness; $G$ decreased significantly in cover-abundance but increased significantly in richness, while $\mathrm{F}$ increased significantly in both cover-abundance and richness (Fig. 2D-E).

NB plots showed a decrease in species richness, diversity and evenness in M96LSu, followed by a subsequent increase until D96LS (Table 3). In B plots, species richness increased from M96LSu to D96LS, and diversity and evenness from J96W to D96LS.

The percent of litter was higher in NB than in B plots. Conversely, the percent of bare soil was higher in B than in NB plots (Table 1). In B plots, the percent of bare soil peaked in M96LSu and decreased thereafter.

The first two PCA factors based on species cover-abundance explain $51.9 \%$ of the total variance (36.6 and $15.3 \%$, for the first and second axes, respectively). The distribution of species and sampling dates on the first two axes (Fig. 3). The first factor would be defined mainly by the cover-abundance of $S$. densiflora. The pre-burned plots in $\mathrm{N} 95 \mathrm{~S}$ and all NB plots are located on the negative side of the axis and defined by high cover-abundance values of $S$. densiflora. The B plots are located on the positive side of the axis and show extremely low cover-abundance values at all sampling dates. The second factor would be defined principally by the seasonal distribution of the different sampling dates and by species characterizing each sampling date. Most of the sampling dates corresponding to NB show a trend to aggregate and are located on the positive side of the axis. Sampling dates

TABLE 2

Wilcoxon's test, T values, P-level and number of repetitions for the percentages of cover-abundance of $S$. densiflora, cover-abundance and richness of perennial species (P), annual species, (A), graminoids $(\mathrm{G})$ and forbs (F) before (N95) and after the fire (D96) in burned and non-burned plots

Prueba de Wilcoxon, valores de T, p-level y repeticiones para los porcentajes de abundancia -cobertura S. densiflora, especies perennes (EP), anuales, (EA), herbáceas graminiformes (HG) y latifoliadas (HL) antes del fuego (N95) y después del fuego (D96) en las parcelas quemadas y no quemadas

\begin{tabular}{|c|c|c|c|c|c|c|}
\hline \multirow[t]{2}{*}{ Cover-abundance (\%) } & \multicolumn{3}{|c|}{ Not burned } & \multicolumn{3}{|c|}{ Burned } \\
\hline & $\mathrm{T}$-value & P-level & Valid $n$ & T-value & P-level & Valid $n$ \\
\hline S.densiflora N95S vs S.densiflora D96LS & 2.000000 & 0.138012 & 5 & 0.0000 & $<0.001$ & 32 \\
\hline P N95S vs P D96LS & 3.000000 & 0.224917 & 5 & 5.0000 & $<0.001$ & 32 \\
\hline A N95S vs A D96LS & 5.000000 & 0.500185 & 5 & 0.0000 & $<0.001$ & 32 \\
\hline G N95S vs G D96LS & 2.000000 & 0.138012 & 5 & 0.0000 & $<0.001$ & 32 \\
\hline F N95S vs F D96LS & 0.000000 & 0.043115 & 5 & 0.0000 & $<0.001$ & 32 \\
\hline \multicolumn{7}{|l|}{ Richness } \\
\hline P N95S vs P D96LS & 0.000000 & 0.108810 & 5 & 2.5000 & $<0.001$ & 32 \\
\hline A N95S vs A D96LS & 2.500000 & 0.177531 & 5 & 0.0000 & $<0.001$ & 32 \\
\hline G N95S vs G D96LS & 2.000000 & 0.592980 & 5 & 0.0000 & $<0.001$ & 32 \\
\hline F N95S vs F D96LS & 3.500000 & 0.280713 & 5 & 0.0000 & $<0.001$ & 32 \\
\hline
\end{tabular}


separated from the others are N95LS, which is related to high cover-abundance of $S$. densiflora, and D96LS, related to the high cover-abundance of $D$. fullanum and A. hastata during the whole study period. The B plots corresponding to the first two sampling dates (M96LSu and J96W) are located on the negative side of this axis and associated with, for example, S. rhombifolia, Ch. album and $C$. dydimus. The censuses made in D96LS, which are located on the positive side of the first axis, are mainly associated with $P$. parviflora, A. leptophyllum, A. tribuloides, M. officinalis, $R$. obovatus, S. leprosa, L. bonariensis and C.vulgare. The NB plots corresponding to D96LS are located close to the B plots, on the positive side of the second axis.

The ordination of species together with the supplementary variables, treatment and sampling date, shows variations in composition and cover-abundance along the first two axes throughout the study period. The ordination on the first factor is likely to be related to the fire disturbance since this axis is mainly determined by the cover-abundance of $S$. densiflora, while the ordination along the second axis would be related to seasonal variations in the dynamics of the system. These variations are more pronounced in the B plots at different dates.

\section{DISCUSSION}

Species registered in NB and B plots can be classified as either halophytes (salt tolerants) or non-halophytes on the basis of their ecophysiological adaptations (Larcher 1995). Halophytes were represented by $S$. densiflora, Salicornia virginica, Limonium brasiliense and Atriplex hastata, and non-halophytes by weeds typically found in agroecosystems of the region (Marzocca 1976, Requesens \& Madanes 1992). Many of these weeds (e.g., M. officinalis, $C$. cardunculus, D. fullanum and A. sellowanium), are common in non-burned salt marshes along coastal areas of Buenos Aires Province (Cagnoni 1999) and in burned and non-burned salt marshes dominated by $S$. argentinensis in the Chaco-Pampean Plain, Argentina (Alzugaray et al. 2003).

TABLE 3

Mean $(\bar{x})$ and standard deviation (SD) of richness. Diversity and evenness in non-burned $(\mathrm{NB}, \mathrm{n}=5)$ and burned $(\mathrm{B}, \mathrm{n}=32)$ plots along the study period: N95S (November 1995, spring), M96LSu (March 1996, late summer), J96W (July 1996, winter), and D96LS (December 1996, late spring)

Media $(\bar{x})$ y desviación estándar (DE) de la riqueza, diversidad y equitatividad de las parcelas no quemadas $(\mathrm{NB}, \mathrm{n}=5)$ y quemadas ( $\mathrm{B}, \mathrm{n}=32$ ) durante el período de estudio: N95S (noviembre 1995, primavera), M96Lsu (marzo1996, verano tardío), J96W (julio 1996, invierno) y D96LS (diciembre 1996, primavera tardía)

\begin{tabular}{|c|c|c|c|c|c|c|}
\hline \multirow[t]{2}{*}{ Variable } & & \multirow[b]{2}{*}{ Treatment } & \multicolumn{4}{|c|}{ Sampling data } \\
\hline & & & N95S & M96LSu & J96W & D96LS \\
\hline \multirow[t]{4}{*}{ Richness } & Mean & NB & 6.60 & 3.60 & 4.40 & 7.60 \\
\hline & SD & & 2.41 & 0.55 & 2.30 & 3.13 \\
\hline & Mean & B & 4.47 & 6.22 & 9.03 & 12.09 \\
\hline & $\mathrm{SD}$ & & 2.44 & 1.48 & 2.18 & 2.37 \\
\hline \multirow[t]{4}{*}{ Diversity } & Mean & NB & 0.72 & 0.08 & 0.32 & 1.25 \\
\hline & $\mathrm{SD}$ & & 0.22 & 0.11 & 0.46 & 0.58 \\
\hline & Mean & B & 0.54 & 0.57 & 0.83 & 1.84 \\
\hline & $\mathrm{SD}$ & & 0.39 & 0.37 & 0.31 & 0.27 \\
\hline \multirow[t]{4}{*}{ Evenness } & Mean & NB & 0.41 & 0.06 & 0.18 & 0.62 \\
\hline & SD & & 0.17 & 0.08 & 0.21 & 0.22 \\
\hline & Mean & B & 0.34 & 0.32 & 0.38 & 0.74 \\
\hline & SD & & 0.23 & 0.22 & 0.14 & 0.10 \\
\hline
\end{tabular}



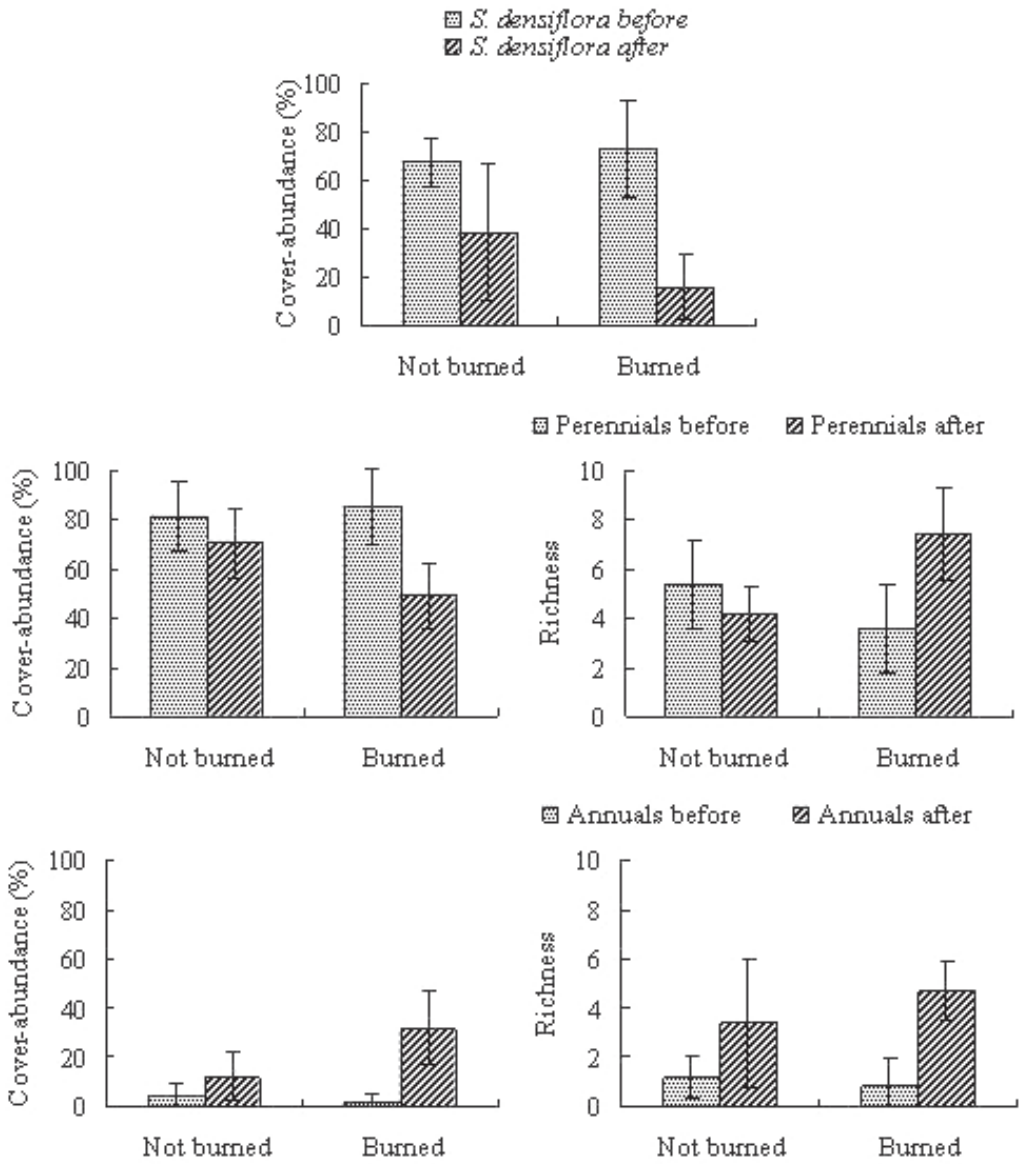

․․․ Annuals before Annuals after
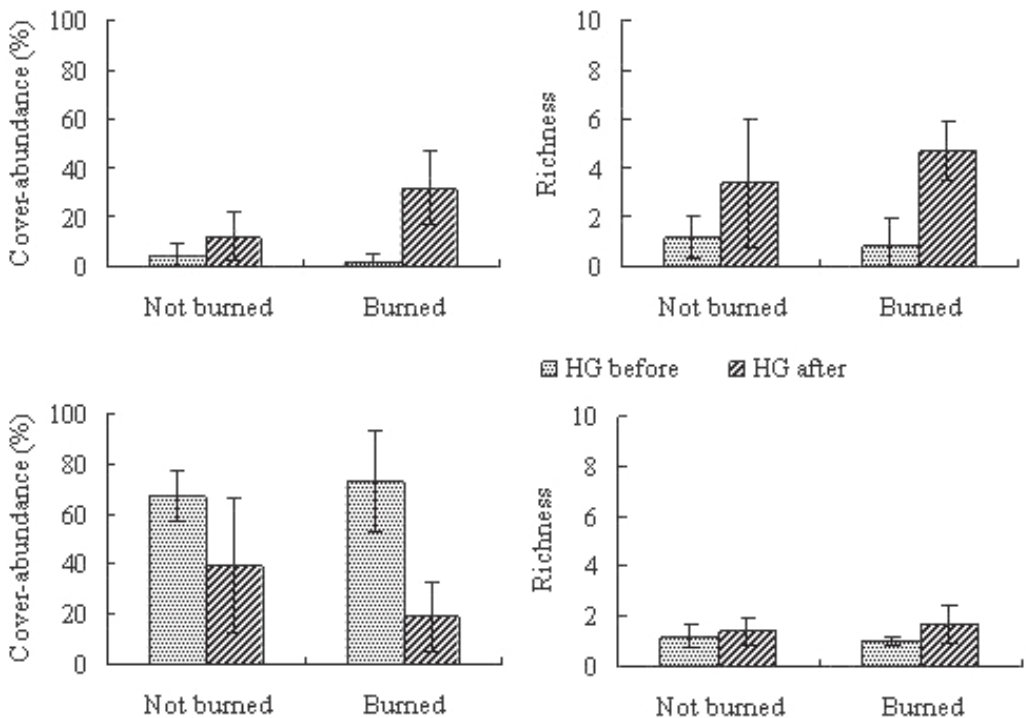

圆 HG before $\because \mathrm{HG}$ after

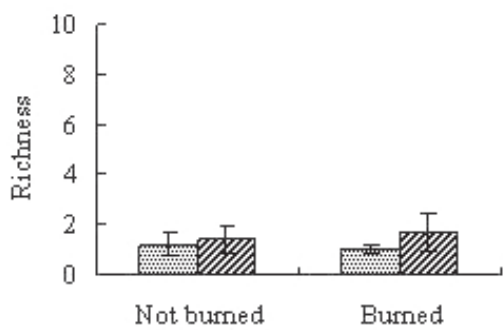

贯 HL before $\square \mathrm{HL}$ after
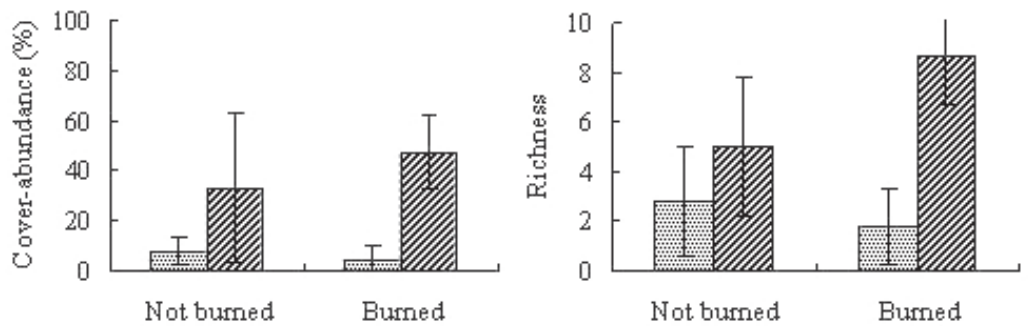

Fig. 2: (A) Mean percent cover-abundance of Spartina densiflora and mean percentage of coverabundance and richness of (B) perennial species, (C) annual species, (D) graminoids, and (E) forbs before ( N95S) and after the fire.

(A) Porcentaje medio de la cobertura-abundancia de Spartina densiflora y porcentaje medio de la abundance-coberture y riqueza (B) de las especies perennes, (C) anuales, (D) herbáceas graminiformes (HG), y (E) latifoliadas antes ( N95S) y al final del período D96LS. 


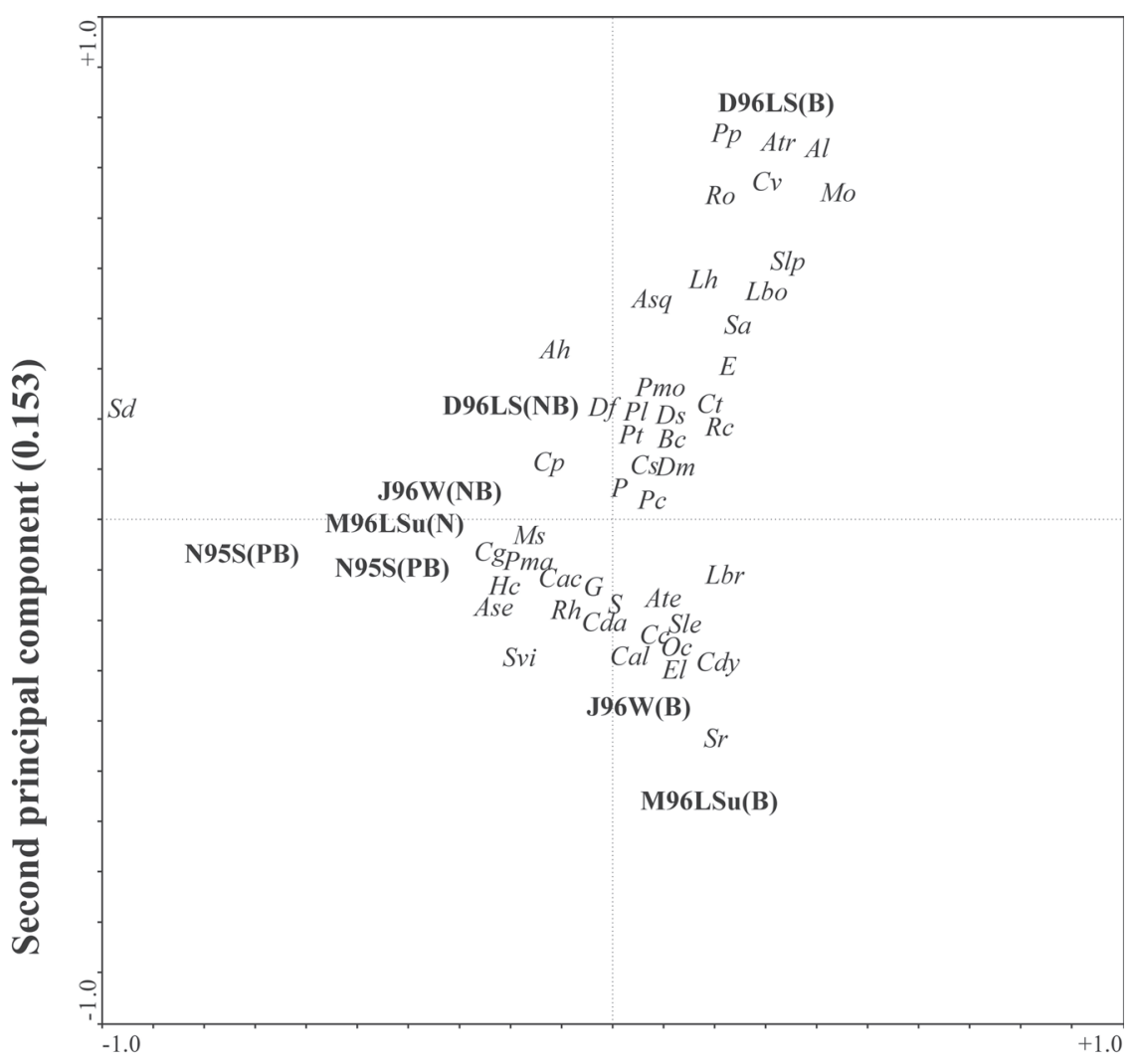

First principal component $(\mathbf{0 . 3 6 6 )}$

Fig. 3: Distribution of species and sampling dates before (PB) and after fire in burned (B) and nonburned (NB) plots in relation to the first two axes of Principal Component Analysis (PCA). Species key: Ah: Atriplex hastate; Al: Apium leptophillum; Ase: Apium sellowianum; Asq: Aster squamatus; Ate: Ambrosia tenuifolia; Atr: Acicarpha tribuloides; Bc: Brassica campestris; Cac: Carduus acanthoides; Cal: Chenopodium album; Cc: Cynara cardunculus; Cda: Cynodon dactylon; Cdy: Coronopus dydimus; Cg: Cerastium glomeratum; Cp: Centaurium pulchellum; Cs: Carex sellowiana; Ct: Cressa truxillensis; Cv: Cirsium vulgare; Df: Dipsacum fullonum; Dm: Dichondra microcalyx; Ds: Distichlis spicata; E: Eleocharis sp.; El: Euphorbia lorentzii; G: Gnaphalium sp.; Hc: Heliotropum curassavicum; Lbo: Lepidium bonariensis; Lbr: Limonium brasiliensis; Lh: Lythrum hyssopifolia; Mo: Melilotus officinalis; Ms: Muehlembeckia sagittifolia; Oc: Oxalis corimbosa; P: Portulacca sp.; Pc: Phyla canescens; Pl: Picrosia longiflora; Pma: Plantago major; Pmo: Polypogon monspeliensis; Pp: Petunia parviflora; Pt: Plantago tomentosa; Rc: Rumex crispus; Rh: Rorippa hilariana; Ro: Rumex obovatus; S: Spergula sp.; Sa: Salicornia ambigua; Sd: Spartina densiflora; Sle: Spergularia levis; Slp: Sida leprosa; Sr: Sida rhombifolia; Svi: Salicornia virginica. Sampling dates were N95S: November 1995, spring; M96Lsu: March 1996, late summer; J96W: July 1996, winter; and D96LS: December 1996, late spring.

Distribución de las especies y fechas de muestreo antes (PB) y después del fuego en parcelas quemadas (B) y no quemadas (NB) producto del ordenamiento de los dos ejes principales del análisis de componentes principales (PCA). Clave de especies: Ah: Atriplex hastata; Al: Apium leptophillum; Ase: Apium sellowianum; Asq: Aster squamatus; Ate: Ambrosia tenuifolia; Atr: Acicarpha tribuloides; Bc: Brassica campestris; Cac: Carduus acanthoides; Cal: Chenopodium album; Cc: Cynara cardunculus; Cda: Cynodon dactylon; Cdy: Coronopus dydimus; Cg: Cerastium glomeratum; Cp: Centaurium pulchellum; Cs: Carex sellowiana; Ct: Cressa truxillensis; Cv: Cirsium vulgare; Df: Dipsacum fullonum; Dm: Dichondra microcalyx; Ds: Distichlis spicata; E: Eleocharis sp.; El: Euphorbia lorentzii; G: Gnaphalium sp.; Hc: Heliotropum curassavicum; Lbo: Lepidium bonariensis; Lbr: Limonium brasiliensis; Lh: Lythrum hyssopifolia; Mo: Melilotus officinalis; Ms: Muehlembeckia sagittifolia; Oc: Oxalis corimbosa; P: Portulacca sp.; Pc: Phyla canescens; Pl: Picrosia longiflora; Pma: Plantago major; Pmo: Polypogon monspeliensis; Pp: Petunia parviflora; Pt: Plantago tomentosa; Rc: Rumex crispus; Rh: Rorippa hilariana; Ro: Rumex obovatus; S: Spergula sp.; Sa: Salicornia ambigua; Sd: Spartina densiflora; Sle: Spergularia levis; Slp: Sida leprosa; Sr: Sida rhombifolia; Svi: Salicornia virginica. Las fechas de muestreo fueron N95S: noviembre 1995, primavera; M96Lsu: marzo1996, verano tardío; J96W: julio 1996, invierno; D96LS: diciembre 1996, primavera tardía. 
Our results indicating a decrease in the cover-abundance of $S$. densiflora after the fire are consistent with those reported by Feldman \& Lewis (2005) for S. argentinensis. However, $S$. densiflora was the dominant species in both $\mathrm{B}$ and $\mathrm{NB}$ plots during the entire study period. The dominance of perennial species following disturbance has been reported by Vicari et al. (2002) in an area adjacent to our study site and by other authors in different salt marshes (Brewer \& Grace 1990, Balwin et al. 1996).

On the other hand, the increase in species richness, evenness and diversity observed in $\mathrm{B}$ plots after the fire were higher than those in NB plots at the same sampling dates. This difference could be explained by the germination and establishment of annual (Laterra et al. 2003, Feldman \& Lewis 2005), and perennial species, and by a variation in the phenology of some species in relation to the pattern that they exhibited in NB plots. The phenological pattern variation was probably due to the early appearance (e.g. $C$. vulgare, A. leptophyllum) and/or the delayed disappearance (e.g. S. rhombifolia, $S$. virginica) of species in response to the disturbance. Both processes, which would result from a decrease in the canopy of the dominant species by the fire, would interfere with the life cycle of the accompanying species and the recruitment of new ones. In general, reduced canopy owing to fire produces salinity changes in some of the patches, thus creating a more oligosaline environment (Baldwin \& Mendelssohn 1998), and an increased availability of resources, mainly light, nutrients and space (Shumway \& Bertness 1992). These changes in the environmental conditions are likely to account for the increased proportion of bare soil and the total elimination of litter recorded in our study site after the fire. In B plots, environmental heterogeneity may have favored the development of accompanying plants (halophytes and non-halophytes) adapted to different saline conditions. In NB plots, the heterogeneity derived from the small proportion of bare soil was low but enough to allow non-halophytes to develop.

At the end of the study, in B plots, $\mathrm{P}$ showed a decrease in cover-abundance and an increase in richness, while both attributes increased for A; the same pattern was followed by $F$, and $G$ showed a decrease in cover abundance and almost similar values of richness. These results suggest that A species (mainly represented by $\mathrm{F}$ ) and some of the $\mathrm{P}$ species may have established at different times after the fire due to (i) their presence in the seed bank (Alzugaray et al. 2003, Feldman \& Lewis 2005), (ii) the arrival of seeds from adjacent agricultural areas, as observed for Brassica campestris and Rumex crispus (Boutin \& Jobin 1998)

On the other hand, some $\mathrm{P}$ such as $S$. densiflora and accompanying species remained alive after the fire because only the aerial parts of the plants were consumed, while rhizomes and stolons were not affected. This in agreement with Alzugaray et al. (2003), who reported that $S$. argentinensis was poorly represented in the seed bank and inferred that the community matrix probably persisted due to tiller emission. In addition, Clakson (1997) postulated that species with rhizomes surviving fire are able to resprout and grow rapidly in the initial post-fire period. In brief, the analysis of the above-mentioned attributes suggests that the $S$. densiflora salt marsh was affected by a non-lethal fire disturbance

The ordination of cover-abundance data and treatments, when considering all sampling dates, shows that NB plots were subject to smooth temporal changes in composition and cover abundance, and that B plots underwent greater changes. In D96LS, B and NB plots exhibited a different spatial distribution, which in turn differed from that observed in pre-fire plots in N95Su. Hence, both disturbed and nondisturbed plots showed no trend to return to pre-fire conditions one year after the fire, but more time is necessary to evaluate the longterm impact of the disturbance on the system.

The effect of the accidental human-caused fire on the $S$. densiflora salt marsh in the Lower Delta of the Paraná River has previously been studied by R. Vicari (unpublished results) in terms of biomass changes, while in the present paper the response of the system to the disturbance was analyzed at a community level. The integration of results obtained from these differing approaches would not only lead to predict future outcomes, but also to provide a basis for management recommendations. 


\section{ACKNOWLEDGEMENTS}

We thank Mr. José Sercombe for his assistance in the field work and the staff of the Otamendi Natural Reserve for technical support. This research was supported by the Adminstración de Parques Nacionales de la República Argentina.

\section{LITERATURE CITED}

ALZUGARAY C, S FELDMAN \& JP LEWIS (2003) Dinámica de los bancos de semillas de un espartillar de Spartina argentinensis. Ciencia e Investigación Agraria (Chile) 30: 197-209.

BALWIN AH \& IA MENDELSSOHN (1998) Response of two oligohaline marsh communities to lethal and nonlethal disturbance. Oecologia 116: 543-555.

BALWIN AH, KL MCKEE \& IA MENDELSSOHN (1996) The influence of vegetation, salinity, and inundation on seed banks of oligohaline coastal marshes. American Journal of Botany 83: 470-479.

BARKMAN J (1988) New systems of plants growth forms and phenological plant types. In: Werger MAJ, PJM. Van Der Aart, HJ During \& JTA Verhoeven (eds) Plant form and vegetation structure: 9-44. SPB Academic Publishing The Hague, The Netherlands.

BONFILS CG (1962). Los suelos del Delta del río Paraná. Factores generadores, clasificación y uso. Revista de Investigaciones Agrícolas (Argentina) 16: $257-370$

BOUTIN C \& B JOBIN (1998) Intensity of agricultural practices and effects on adjacent habitats. Ecological Applications 8: 544-557.

BRAUN-BLANQUET J (1979). Fitosociología. Bases para el estudio de las comunidades vegetales. Blume Ediciones, Barcelona, España. 820 pp.

BREWER JS \& JB GRACE (1990) Plant community structure in an oligohaline tidal marsh. Vegetatio 90: 93-107

CABRERA AL \& A WILLINK (1980) Biogeografía de América Latina. Organización de Estados Americanos, Serie Biología 13, Washington, Distrit of Columbia, USA. 122 pp.

CABRERA AL \& EM ZARDINI (1993) Manual de la flora de los alrededores de Buenos Aires. Second edition. ACME Press, Buenos Aires, Argentina. 754 pp

CAGNONI M (1999) Espartillares de la costa bonaerense de la República Argentina. Un caso de humedales costeros. En: Malvárez AI (ed) Tópicos sobre humedales subtropicales y templados de Sudamérica: 55-69. Universidad de Buenos Aires, Programa sobre el Hombre y la Biósfera de la UNESCO, Montevideo, Uruguay.

CHICHIZOLA SE (1993) Las comunidades vegetales de la Reserva Natural Estricta Otamendi y sus relaciones con el ambiente. Parodiana (Argentina) 8: 227-263.

CLAKSON BR (1997) Vegetation recovery following fire in two Waikato peatlands at Whangamarino and Moanatuatua, New Zealand. New Zealand Journal of Botany 35: 167-179.

FELDMAN SR \& JP LEWIS (2005) Effects of fire on the structure and diversity of a Spartina argentinensis tall grassland. Applied Vegetation Science 8: 77-84.

GRACE JB, MD SMITH, SL GRACE, SL COLLINS \& TJ STOHLGRENN (2001) Interactions between fire and invasive plants in temperate grassland of North America. In: Galley KLM \& Wilson TP (eds) Proceedings of the invasive species workshop: the role of fire in the control and spread of invasive species: 40-65. Tall Timbers Research Station, Tallahasee, Florida, USA

GRIME JP (1979) Plant strategies and vegetation processes. Wiley \& Sons, New York, New York, USA. 222 pp.

HULBERT LC (1988) Causes of fire effects in tall grass prairie. Ecology 69: 46-58.

INTA (1998) Datos meteorológicos. Estación Otamendi. Serie 1979-1995. Instituto Nacional de Tecnología Agropecuaria, Buenos Aires, Argentina. $21 \mathrm{pp}$

IRIONDO M \& E SCOTTA (1978) The evolution of the Paraná River Delta. In: Proceedings of the International Symposium on Coastal Evolution in the Quaternary: 405-418. INQUA, Sao Paulo, Brazil. (si se cita como capítulo de libro se debe indicar datos de los editores.

JUBER JG \& M ENTROCASI (2000) Administración de parques nacionales. Reserva Natural Otamendi. Plan de protección contra incendios forestales. Informe Técnico. Administración de Parques Nacionales, Buenos Aires, Argentina. 152 pp.

KANDUS P, AI MALVÁREZ \& N MADANES (2004). Estudio de las comunidades de plantas naturales de las islas del Bajo Delta del Río Paraná. Darwiniana (Argentina) 41: 1-16.

LARCHER W (1995) Physiological plant ecology. Ecophysiology and stress physiology of functional groups. Third edition. Springer-Verlag, New York, New York, USA. 505 pp.

LATERRA P, OR VIGNOLO, MP LINARES, A GIAQUINTA \& N MACEIRA (2003) Cumulative effects of fire on a tussock pampa grassland. Journal Vegetation Science 14: 43-54.

LEWIS JP, EF PIRE, DE PRADO, SL STOFELLA, EA FRANCHESCHI \& NJ CARNEVALE (1990) Plant communities and phytogeographycal position of a large depression in the Great Chaco, Argentina. Vegetatio 86: 25-28

MAGURRAN AE (1991) Ecological diversity and its measurement. Chapman \& Hall Press, London, United Kingdom. 178 pp.

MALVÁREZ AI \& RF BÓ (2002) en el Delta medio del río Paraná debidos al evento de El Niño 1982-1983. In: Chanak EJS (ed) Contribuciones. Taller: El Niño: sus impactos en El Plata y en la región Pampeana: 27-31. Comisión de Investigaciones Científicas de la Provincia de Buenos Aires, Asociación Bonaerense de Científicos, Facultad de Ciencias Naturales y Museo, Universidad Nacional de La Plata. La Plata, Argentina.

MARZOCCA A (1976) Manual de malezas. Third edition. Hemisferio Sur Press, Buenos Aires, Argentina. 564 pp.

MITSCH WV \& JG GOSSELINK (2000) Wetlands. Third edition. John Wiley \& Sons Press, New York, New York, USA. $920 \mathrm{pp}$

MUELLER-DOMBOIS D \& E ELLEMBERG (1974) Aims and methods of vegetation ecology. John Wiley \& Sons Press, New York, New York, USA. 547 pp.

NEKOLA JC \& TG LAMMERS (1989) Vascular flora of the Brayton-Horsely prairie: a remnant prairie and spring fen complex in eastern Iowa. Castanea (USA) 54: 238-254

NYMAN JA \& RH CHABRECK (1995) Fire in coastal marsh history and recent concerns. In: Cerulean SI \& RT Engstron (eds) Proceedings 19th tall timbers 
fire ecology conference-fire in wetlands: a management perspective: 135-141. Tall Timbers Research, Inc., Tallahassee, Florida, USA.

ORME AR (1990) Wetland morphology, hydrodynamics and sedimentation. In: Williams M (ed) Wetlands: a threatened landscape: 42-94. Institute of British Geographers, Blackwell Science Press, Oxford, United Kingdom. 419 pp.

PETETIN CA \& E MOLINARI (1977) Clave ilustrada para el reconocimiento de malezas en el campo al estado vegetativo. Instituto Nacional de Tecnología Agropecuaria, Instituto Nacional de Tecnología Agropecuaria, Buenos Aires, Argentina. 243 pp.

RAUNKIAER C (1937) The life form of plant and stadistical plant geography. Claredon Press, Oxford, United Kingdom. 104 pp.

REQUESENS E \& N MADANES (1992) Organización de comunidades estacionales de malezas en el sudeste de la Provincia de Buenos Aires. Ecología Austral (Argentina) 2: 101-108.

SHUMWAY SW \& MD BERTNESS (1992) Salt stress limitation of seedling recruitment in a salt marsh plant community. Oecología 92: 490-497.

TER BRAAK CJ (1995) Ordination. In: Jongman RHG, CJF Ter Braak \& OFR Van Tongeren (eds) Data analysis in communities and landscape ecology: 91169. Cambridge University Press, New York, New York, USA.

VICARI R, S FISCHER, $\mathrm{N}$ MADANES, S BONAVENTURA \& V PANCOTTO (2002) Tiller population dynamics and production of Spartina densiflora (Brong) on the floodplain of the Paraná River (Argentina). Wetlands 22: 347-354.

ZAR J (1996) Biostatistical analysis. Third edition, Prentice Hall, Englewood Cliffs, New Jersey, USA. $718 \mathrm{pp}$. 
